\title{
sciendo
}

Folia Oeconomica Stetinensia

Volume 20 (2020) Issue 2

DOI: $10.2478 /$ foli-2020-0061
WYDZIAL NAUK EKONOMICZNYCH I ZARZAQDZANIA

\section{CULTURAL DIFFERENCES IN A RESTAURANT'S COMMUNICATION WITH UNSATISFIED CUSTOMERS - THE CASE OF TRIPADVISOR}

\author{
Agnieszka Żbikowska, Ph.D., Associate Professor \\ Cracow University of Economics \\ College of Management and Quality Sciences \\ Department of Marketing \\ Rakowicka 27, 31-510 Kraków, Poland \\ e-mail: zbikowska@uek.krakow.pl \\ ORCID: 0000-0003-4216-1817
}

Received 2 February 2020, Accepted 2 April 2020

\begin{abstract}
Research background: Platforms such as TripAdvisor have the potential to influence consumers' decisionmaking processes, so negative user-generated reviews could have a harmful impact on a company's reputation and sales. However, the proper mangers' approach to customer complaints expressed on social media can have a positive impact on the companies' performance.

Purpose: The aim of the study is to indicate whether restaurant managers use TripAdvisor to communicate with dissatisfied customers and whether national culture influences this communication.

Research methodology: The methods used in the research were both a quantitative and qualitative content analyses of restaurants' responses to negative reviews posted on TripAdvisor. The research covered a random sample of restaurants located in Cracow (Poland), Frankfurt (Germany) and Porto (Portugal), and listed on TripAdvisor.

Results: The research showed that differences in communication, which may result from dissimilar cultural conditions, are relatively small.

Novelty: The research shows whether and to what extent restaurant managers respond to negative comments posted on TripAdvisor. At the same time, research results indicate whether the responses of managers are culturally determined.
\end{abstract}

Keywords: culture, marketing communication, customer dissatisfaction, social media, TripAdvisor

JEL classification: M31, L83 


\section{Introduction}

Culture - as an element of the environment of any company - can determine the enterprise's activities on many levels. Managers' beliefs, values or attitudes, which are part of their national culture, influence both the broadly understood business management strategy and the manner of implementing individual tasks. Technological development and progressing globalization lead to cultural convergence, i.e. the emergence of similar products of a culture in various communities. At the same time, there is also a visible cultural divergence, which means not so much the rejection by communities of values dominating in other cultures but emphasizing and strengthening their own attitudes or beliefs. Both phenomena - convergence and divergence have been scientifically confirmed. This is a paradox - national cultures are globalized and at the same time remain unique (Aïssaoui, Fabian, 2015).

From this perspective, it is interesting whether the use of the latest technologies by managers from different countries in communication with consumers remains under the influence of national cultures. One of the tools for communication between enterprises and consumers is TripAdvisor, available in 49 markets, in countries with different cultures. TripAdvisor (2019) notes a monthly average of 490 million unique users who already have posted nearly 8 million reviews. According to Statista (2019) in 2018, there were more than 1.3 million restaurants listed on TripAdvisor. Some customers express their dissatisfaction with services by writing negative reviews. On the one hand, this can be harmful to both the volume of sales and the company's image. On the other hand, comments posted by enterprises can be not only a response to a complaint from a dissatisfied customer but also a positive signal for potential consumers, playing an educational role.

Therefore, the aim of the study is to indicate whether restaurant managers use TripAdvisor to communicate with dissatisfied customers and whether national culture influences this communication. The article successively presents the theoretical background and the results of previous research on the discussed issues, the research method, findings and discussion, and conclusions.

\section{Theoretical background}

Many researchers show that culture can influence company strategies and the tools they use (Dorfman, Javidan, Hanges, Dastmalchian, House, 2012; Hofstede, Hofstede, 2007; Trompenaars, Hampden-Turner, 2002; Gesteland, 2002). Certainly, the most obvious is the impact of culture on human resource management, the shape of marketing tools or the way 
of negotiating with business partners (Wiktor, 2017). It is also worth noting that many authors emphasize the importance of cultural differences in marketing communication with consumers (Harvey, Griffith, 2002; Guo, Cheung, Leung, 2012). In the context of electronic communication with consumers, van Mulken and van der Meer (2005) conducted some interesting research. They showed that there are cultural differences between American and Dutch companies that used email to communicate with customers.

According to the disconfirmation of the expectations theory developed by Oliver (1980), dissatisfaction occurs when consumer experience of using a product is lower than his/ her expectations. Churchill and Surprenant (1982) indicate that neither the disconfirmation experience nor customers' initial expectations affect customers' satisfaction. Customer satisfaction or dissatisfaction is determined rather by the performance of the product. This theory, however, applies primarily to durable goods. Instead, Parasuraman, Zeithaml and Berry (1994) define customer satisfaction in services as the discrepancy between customers' expectations and perceptions. Similarly, Boulding, Staelin, Kalra and Zeithaml (1993) describes satisfaction as a model of prior expectations and the perception of the actually delivered service.

Undoubtedly, a satisfied customer is a prerequisite for the success of any restaurant. (Chow, Lau, Lo, Sha, Yun, 2007). Unsatisfied customers cannot only resign from further purchases but also negatively affect the reputation of a restaurant. In the era of social media development, the voice of every dissatisfied customer can reach many potential buyers. According to HennigThurau, Gwinner, Walsh and Gremler (2004), word-of-mouth and negative comments allow consumers to gain collective power over companies. Ayeh, Au and Law (2013) suggest that platforms such as TripAdvisor have the potential to influence consumers' travel planning and decision-making process, so negative user-generated reviews could have a harmful impact on the company's reputation and sales. It can be assumed that these conclusions are also true for other groups of services assessed on TripAdvisor. Furthermore, negative reviews can even lead to serious crises in companies (Liu, Pennington-Gray, Donohoe, Omodior, 2015).

However, it should be noted that research conducted by Cho (2013) shows that complaining behavior leads to repeat purchase intention on the condition that complaints are well resolved. At the same time, Hsiao, Chen, Choy and Su (2016) argues that individual complaint handling is not enough to improve the quality of services in the long term - consumer complaints should also be analyzed at an aggregate level. Thus, the proper mangers' approach to customer complaints expressed on social media can have a positive impact on restaurant performance. 
Therefore, the aim of the study is to indicate whether restaurant managers use TripAdvisor to communicate with dissatisfied customers and whether national culture influences this communication.

\section{Method}

The methods used in the research were both quantitative and qualitative content analyses of restaurant responses to negative reviews (with a rating of 1 or 2) posted on TripAdvisor. The research covered a random sample of restaurants located in Cracow (Poland), Frankfurt (Germany) and Porto (Portugal) - see Table 1.

Table 1. Selection of the research sample

\begin{tabular}{|l|c|c|c|}
\cline { 2 - 4 } \multicolumn{1}{c|}{} & Cracow & Frankfurt & Porto \\
\hline Number of restaurants listed on TripAdvisor & 1,530 & 1,992 & 1,856 \\
\hline Number of restaurants with reviews & 1,394 & 1,843 & 1,744 \\
\hline Sample size & 301 & 320 & 315 \\
\hline
\end{tabular}

Source: own elaboration.

Both Krakow (771,000 residents) and Porto (about 215,000) are the second-largest cities in Poland and Portugal, respectively. For both cities, 2018 was a record year in terms of the number of tourists - 13.5 million people visited Cracow, and 1.6 million decided to visit Porto. In the same year, Frankfurt (inhabited by 748,000 people) was visited by over 5.9 million visitors. From this perspective, Cracow, Frankfurt, and Porto have some similar features - these are relatively large cities with a significant number of tourists per resident. At the same time, these cities are influenced by different national cultures. This is demonstrated, for example, by the GLOBE project (Culture Groups, 2004). Germany is included in the Germanic Europe cluster; Poland belongs to the Eastern European group, and Portugal - to the Latin Europe cluster. Differences between countries are also visible in the Hofstede model of national culture (The 6 dimensions..., 2019).

The basic characteristics of the tested sample are shown below in Table 2. TripAdvisor allows for specifying the price range of meals offered in restaurants: Fine Dining with the highest prices, Mid-range and Cheap Eat. The rating on a scale of 1 to 5 is determined for each restaurant (with 1 being the lowest rate). Restaurant managers can manage their company profiles on TripAdvisor (e.g. upload photos, respond to reviews). 
Table 2. The characteristics of the sample

\begin{tabular}{|l|c|c|c|c|}
\hline \multirow{4}{*}{ Variable } & \multirow{2}{*}{ Variable value } & \multicolumn{3}{|c|}{ Percentage of restaurants } \\
\cline { 2 - 5 } & & Cracow & Frankfurt & Porto \\
\hline \multirow{4}{*}{ Price } & Fine Dining & 9.3 & 5.3 & 2.5 \\
\cline { 2 - 5 } & Mid-range & 51.8 & 54.7 & 53.0 \\
\cline { 2 - 5 } & Cheap Eats & 38.9 & 17.5 & 35.6 \\
\cline { 2 - 5 } & Not specified & 0.0 & 22.5 & 9.2 \\
\hline \multirow{3}{*}{ Rating } & 5 & 9.3 & 12.1 & 11.8 \\
\cline { 2 - 5 } & 4.5 & 43.5 & 34.5 & 34.9 \\
\cline { 2 - 5 } & 4 & 30.6 & 33.9 & 33.3 \\
\cline { 2 - 5 } & 3.5 & 12.6 & 11.5 & 12.1 \\
\cline { 2 - 5 } & 3 & 2.7 & 5.6 & 5.1 \\
\cline { 2 - 5 } & 2.5 & 1.3 & 2.4 & 2.5 \\
\cline { 2 - 5 } & 2 & 0.0 & 30.3 & 0.3 \\
\hline \multirow{3}{*}{ Listing managed by the restaurant } & Yes & 66.5 & 33.1 & 52.1 \\
\hline \multirow{2}{*}{$\begin{array}{l}\text { At least one negative comment (with a rating } \\
\text { of 1 or 2) in the official language or in English }\end{array}$} & No & 33.5 & 66.9 & 47.9 \\
\cline { 2 - 5 } & Yes & 83.7 & 72.5 & 78.1 \\
\hline
\end{tabular}

Source: own elaboration.

It is worth noting that the further analysis considers only the restaurants which received from customers at least one negative review of 1 or 2 (on a scale of 1-5) in the official language (Polish, German or Portuguese) or in English. Subsequently, only the restaurants that responded to at least one negative comment were examined: 62 restaurants from Cracow, 29 from Frankfurt, and 66 from Porto. For checking the independence of variables, Pearson's chi-squared test $(\chi 2)$ was used. The Kruskal-Wallis test was also used in the analysis.

\section{Findings and discussion}

To be able to comment on consumer reviews, restaurants must first decide to manage their profile on TripAdvisor. There are significant differences between restaurants located in different countries: in Cracow, nearly $2 / 3$ of restaurants manage their listings, in Porto - about half of the units, and in Frankfurt - only 1/3. This is one of the reasons why the minority of restaurants respond to negative consumer reviews $-12.5 \%$ in Frankfurt, $24.6 \%$ in Cracow, and 26.8\% in Porto. It can be assumed that huge numbers of tourists visited Cracow (13.5 million in 2018) make the demand for catering services very high and restaurants ignore the critical remarks 
of their guests. However, Frankfurt, a city of similar size, visited by fewer tourists, has more restaurants and less often communicates with dissatisfied customers. For this reason, the volume of demand and supply on the restaurant market cannot be an explanation of various responses to customer criticism.

Perhaps these results are partly explained by the GLOBE project, which points to the varying levels of assertiveness in the countries studied. German residents are the least assertive, confrontational and aggressive in their relationships with others as compared with the Portuguese. Poles are the most assertive. Possibly, German managers do not have a strong need to express their opinions and confront them with consumer assessments.

The likelihood of responding to unfavorable comments increases with the level of prices in a restaurant. This relationship is significant for all cities. Higher prices and the etiquette of "Fine Dining" are usually associated with a higher quality of services including communication with guests.

It is worth noting, however, that restaurant managers only communicate with some authors of negative reviews. If restaurants decide to respond to unfavorable comments at all, only - on average - 33\% of critical remarks in Frankfurt, 40\% in Cracow and 54\% in Porto met with a restaurant reaction. Vásquez (2011) indicates that some complaints (negative reviews) also contain positive remarks. At the same time, advice and recommendations appear in many critical opinions. These elements can mitigate the negative overtones of comments and distract managers from entering a dialogue with consumers.

For the purpose of the analysis, the answers given by restaurant managers were divided into 3 groups - positive, neutral and negative.

In the positive responses, restaurants agree with dissatisfied customers. Managers apologize for the inconvenience and mistakes of restaurant staff. In this group of answers, there were also requests for direct contact with the restaurant. Examples of such answers are:

- if you change your mind and want to give us another chance, please contact our manager Regina. She will take care of you personally;

- we are sorry that you had a negative experience with us. We have already spoken to the waiter who made this error to make sure that it will not happen again.

In neutral responses, restaurant managers say they are sorry about customer dissatisfaction, but at the same time, they explain the intricacies of the catering business (e.g. stating that customers have different tastes) and defend their point of view. Managers emphasize tradition and many years of experience of restaurant staff. These answers are often educational - e.g. 
managers stress that they cannot accommodate customers when all tables are reserved. Examples of such answers are:

1. Thank you very much for your comments. Our menu is updated regularly to meet the expectations of guests from different parts of the world as well as residents [sic].

2. Thank you very much for your feedback. We are very sorry that we had to disappoint you. It is fair time and the restaurant was full. Usually, you can wait at the bar for a free table but there were already several guests waiting [sic].

Negative responses are those that may offend customers. For example:

1. Nothing to say apart from that your critique shouldn't be on TripAdvisor, but that's not your fault unless you had a brain [sic].

2. Luckily you are not Pinocchio, Mr. S. In this case, your nose would have grown tremendously [sic].

The percentages of specific responses are shown in Table 3.

Table 3. Distribution of types of answers

\begin{tabular}{|l|c|c|c|}
\hline \multicolumn{1}{|c|}{ Type of answers } & Cracow & Frankfurt & Porto \\
\hline Positive & 31.9 & 14.9 & 15.5 \\
\hline Neutral & 57.3 & 71.7 & 73.0 \\
\hline Negative & 10.8 & 13.4 & 11.5 \\
\hline
\end{tabular}

Source: own elaboration.

It is worth noting that the percentages of negative responses are relatively low and is similar in all of the three countries. In the case of positive and neutral responses, the reasons were found to reject the null hypothesis of equal averages. Post-hoc tests showed the differences between the average response rates in Porto and in Cracow (for both types of responses) - see Table 4.

According to the Hofstede model, Portugal compared to Poland is a much more collectivist country. Also, studies within the GLOBE project confirm a high degree of Portugal's institutional collectivism. Perhaps this is the reason for differentiated responses to consumer criticism. On the one hand, a restaurant and its employees are treated as a group. On the other hand, loyalty is paramount and over-rides most other societal rules and regulations. Therefore, customers in Portugal can be perceived as not belonging to the group, especially if they are tourists and managers do not have to be overly kind to them. 
Table 4. The Kruskal-Wallis test for the country of the restaurant's location and the type of response to negative comments

\begin{tabular}{|c|c|c|c|}
\hline \multirow{2}{*}{$\begin{array}{l}\text { Dependent variable: } \\
\text { Percentage } \\
\text { of positive responses }\end{array}$} & \multicolumn{3}{|c|}{$\begin{array}{l}\text { P-value for multiple (two-sided) comparisons; } \\
\text { Independent (grouping) variable: Country } \\
\text { The Kruskal-Wallis test: } \mathrm{H}(2, \mathrm{~N}=157)=12.53359 ; \mathrm{p}=0.0019\end{array}$} \\
\hline & $\begin{array}{c}\text { Porto } \\
\text { R:68.856 }\end{array}$ & $\begin{array}{c}\text { Cracow } \\
\text { R:93.694 }\end{array}$ & $\begin{array}{l}\text { Frankfurt } \\
\text { R:70.672 }\end{array}$ \\
\hline Portugal (Porto) & - & 0.006030 & 1.000000 \\
\hline Poland (Cracow) & 0.006030 & - & 0.073218 \\
\hline Germany (Frankfurt) & 1.000000 & 0.073218 & - \\
\hline \multirow{2}{*}{$\begin{array}{l}\text { Dependent variable: } \\
\text { Percentage } \\
\text { of neutral responses }\end{array}$} & \multicolumn{3}{|c|}{$\begin{array}{l}\text { P-value for multiple (two-sided) comparisons; } \\
\text { Independent (grouping) variable: Country } \\
\text { The Kruskal-Wallis test: } \mathrm{H}(2, \mathrm{~N}=157)=9.013308 \mathrm{p}=.0110\end{array}$} \\
\hline & $\begin{array}{c}\text { Porto } \\
\mathrm{R}: 87.871\end{array}$ & $\begin{array}{c}\text { Cracow } \\
\text { R: } 65.952\end{array}$ & $\begin{array}{l}\text { Frankfurt } \\
\text { R:86.707 }\end{array}$ \\
\hline Portugal (Porto) & - & 0.006030 & 1.000000 \\
\hline Poland (Cracow) & 0.006030 & - & 0.073218 \\
\hline Germany (Frankfurt) & 1.000000 & 0.073218 & - \\
\hline
\end{tabular}

Source: own elaboration.

\section{Conclusions}

The survey shows restaurant managers' reactions to user-generated content on TripAdvisor and presents how they communicate with dissatisfied customers using this portal. This is a different view because previous research has mainly focused on the perspective of consumers. The research shows that restaurants still have great opportunities to improve their communication with customers. Dialogue with unsatisfied guests can be an indication to TripAdvisor users that restaurants place a high value on customer service. Certainly, intensive communication can become a distinguishing feature of the company and at the same time it can help to build customer loyalty.

The study considers cultural differences to a limited extent - only 3 countries were considered. It would be interesting to investigate whether TripAdvisor users pay attention to the content of negative reviews, and particularly to the responses to critical comments. 


\section{References}

Aïssaoui, R., Fabian, F. (2015). The French paradox: implications for variations in global convergence. Journal of International Management, 1, 31-48.

Ayeh, J.K., Au, N., Law, R. (2013). Do we believe in TripAdvisor? Examining credibility perceptions and online travelers' attitude toward using user-generated content. Journal of Travel Research, 52, 437-452. DOI: 10.1177/0047287512475217.

Boulding, W., Staelin, R., Kalra, A., Zeithaml, V.A. (1993). A Dynamic process model of service quality: From expectations to behavioral intentions. Journal of Marketing Research, 30, 7-27. DOI: $10.2307 / 3172510$.

Cho, Y.C. (2013). Exploring relationship among customer dissatisfaction, complaints, and loyalty in the virtualized environment: Roles of advanced services. The International Business \& Economics Research Journal, 12 (11), 1343-1360. DOI: 10.19030/iber.v12i11.8381.

Chow, I.H., Lau, V.P., Lo, T.W., Sha, Z., Yun, H. (2007). Service quality in restaurant operations in China: Decision- and experiential-oriented perspectives. International Journal of Hospitality Management, 26 (3), 698-710. DOI: 10.1016/j.ijhm.2006.07.001.

Churchill, G., Surprenant, C. (1982). An Investigation into the Determinants of Customer Satisfaction. Journal of Marketing Research, 19 (4), 491-504. DOI: 10.2307/3151722.

Culture groups (2004). Retrieved from: https://globeproject.com/results?page_id=country\# cluster.

Dorfman, P., Javidan, M., Hanges, P., Dastmalchian, A., House, R. (2012). GLOBE: A twenty year journey into the intriguing world of culture and leadership. Journal of World Business, 47, 504-518. DOI: 10.1016/j.jwb.2012.01.004.

Gesteland, R. (2002). Cross-Cultural Business Behavior. Marketing, Negotiating, Sourcing and Managing Across Cultures. Copenhagen: Copenhagen Business School Press, 2002.

Guo, G., Cheung, F., Leung W.-F. (2012). Cross-Cultural Differences in Attitude towards TV Advertising among Beijing, Hong Kong and Warwick Viewers. International Journal of Integrated Marketing Communications, 4 (1), 43-60.

Harvey, M.G., Griffith, D.A. (2002). Developing effective intercultural relationships: The importance of communication strategies. Thunderbird International Business Review, 44 (4), 455-476. DOI: 10.1002/tie.10029.

Hennig-Thurau, T., Gwinner, K.P., Walsh, G., Gremler, D.D. (2004). Electronic word-of-mouth via consumer-opinion platforms: What motivates consumers to articulate themselves on the Internet? Journal of Interactive Marketing, 18 (1), 38-52. DOI: 10.1002/dir.10073.

Hofstede, G., Hofstede, G.J. (2007). Kultury i organizacje. Zaprogramowanie umystu. Warszawa: PWE. 
Hsiao, Y.-H., Chen, L.-F., Choy, Y.L., Su C.-T. (2016). A novel framework for customer complaint management. The Service Industries Journal, 36 (13-14), 675-698. DOI: 10.1080/02642069.2016.1272592.

Liu, B., Pennington-Gray, L., Donohoe, H., Omodior, O. (2015). New York City bed bug crisis as framed by tourists on Tripadvisor. Tourism Analysis, 20 (2), 243-250. DOI: 10.3727/1 $08354215 X 14265319207597$.

Oliver, R.L. (1980), A cognitive model of the antecedents and consequences of satisfaction decisions. Journal of Marketing Research, 2 (3), 460-469. DOI: 10.2307/3150499.

Parasuraman, A., Zeithaml, V., Berry, L. (1994). Reassessment of expectations as a comparison standard in measuring service quality: Implications for further research. Journal of Marketing, 58 (1), 111-124. DOI: 10.1177/002224299405800109.

Statista (2019). Number of listings on TripAdvisor worldwide from 2014 to 2018. Retrieved from: www.statista.com/statistics/684895/tripadvisor-number-of-listings-by-type.

The 6 dimensions of national culture (2019). Retrieved from: www.hofstede-insights.com/models/national-culture.

TripAdvisor (2019). About TripAdvisor. Retrieved from: tripadvisor.mediaroom.com/usabout-us.

Trompenaars, F., Hampden-Turner, Ch. (2002). Siedem wymiarów kultury. Znaczenie różnic kulturowych $w$ działalności gospodarczej. Kraków: Oficyna Ekonomiczna.

Van Mulken, M., van der Meer, W. (2005). Are you being served? A genre analysis of American and Dutch company replies to customer inquiries. English for Specific Purposes, 24 (1), 93-109. DOI: 10.1016/j.esp.2004.07.001.

Vásquez, C. (2011). Complaints online: The case of TripAdvisor. Journal of Pragmatics, 43, 1707-1717. DOI: 10.1016/j.pragma.2010.11.007.

Wiktor, J. (ed.) (2017). Zarządzanie przedsiębiorstwem międzynarodowym. Integracja różnorodności. Warszawa: C.H. Beck. 